\title{
The Tangled Path From Identifying Financial Assets to Cross-Border Confiscation. Deficiencies in EU Asset Recovery Policy
}

\author{
Ariadna Helena Ochnio \\ PhD, Polish Academy of Sciences, Institute of Law Studies, Warsaw, Poland \\ ariadnaochnio@gmail.com
}

\begin{abstract}
The article discusses the shortcomings of EU policy regarding cross-border asset recovery. The identified problem is a disjointed approach to the overlapping objectives of criminal proceedings: gathering evidence and securing assets for future confiscation. In the current EU legal framework, the process of recovery of assets, understood as a sequence of functionally related activities, lacks the continuity necessary to be effective. EU cross-border cooperation instruments in criminal matters do not meet the needs of this process, as they relate to separate investigative measures. Problems in this field have been indirectly reflected in the practice of Eurojust and the EJN. The article proposes a change in the perception of the initial phase of the asset recovery process, where the objectives of identifying and locating financial assets are combined with their provisional securing. This takes place under one mechanism of cross-border cooperation (an EIO), prior to issuing a regular freeze or seizure order.
\end{abstract}

\section{Keywords}

cross-border confiscation - asset recovery - proceeds of crime - European Investigation Order (EIO) - freezing and seizure of assets - mutual recognition of freezing orders and confiscation orders - cross-border cooperation in criminal matters 


\section{Introductory Remarks}

EU policy aspires to deal comprehensively with the issue of depriving criminals of the proceeds of crime. This is reflected in the concept of "recovery of assets," understood not as a single activity, but as a set of activities that make up a more complex process. Starting with the identification and tracking of assets related to crime, their freezing and seizure for the purpose of confiscation, then management, and ending with effective confiscation and disposal in accordance with national rules, preferably taking into account social and public interests. The Basel Institute on Governance presents a similar approach to the concept of asset recovery with a difference in the criteria identifying the individual phases of the process, focused on the period of activities: pre-investigative, investigative, judicial, or disposal of assets. ${ }^{1}$ At the same time, the Basel Institute's guidelines regarding asset recovery try to break the traditional perception of these phases. ${ }^{2}$ As has rightly been pointed out in the subject literature, the whole process, although based on laws of confiscation or forfeiture, is initiated well before and continues after final deprivation of assets. ${ }^{3}$ However, this is not the only possible arrangement of the narrative components when describing the concept of asset recovery. A different, narrower understanding of the term "asset recovery" is presented, for example, at the Financial Action Task Force (FATF) forum, where it stands for cross-border return of assets, repatriation or asset sharing 4 or the United Nations (UN) forum, where it stands for cross-border return and disposal of assets linked with corruption and related offences. ${ }^{5}$ It is worth noting that

1 Basel Institute on Governance, International Center for Asset Recovery (ICAR), Tracing Illegal Assets. A Practioner's Guide, 2015, pp. 19-2o, https://baselgovernance.org/sites/default/ files/2019-o1/tracing_illegal_assets_EN.pdf (22.02.2021).

2 International Centre for Asset Recovery, Swiss Federal Department of Foreign Affairs, the Stolen Asset Recovery Initiative (StAR) of the World Bank and United Nations Office on Drugs and Crime (UNODC), Guidelines for the efficient recovery of stolen assets, 2017, p. 2. https://learn.baselgovernance.org/pluginfile.php/6239/mod_resource/content/4/Asset\%2O recovery\%2oguidelines.pdf (22.02.2021).

3 K. Ligeti, M. Simonato, 'Asset Recovery in the EU: Towards a Comprehensive Enforcement Model beyond Confiscation? An Introduction', in K. Ligeti, M. Simonato, eds., Chasing Criminal Money. Challenges and Perspectives on Asset Recovery in the EU (Oxford, Portland: Hart Publishing, 2017) pp. 3-4.

4 FATF, Best Practices on Confiscation (Recommendations 4 and 38) and a Framework for Ongoing Work on Asset Recovery, October 2012, p. 10. https://www.fatf-gafi.org/media/fatf/ documents/reports/Best\%2oPractices\%20on\%20\%2oConfiscation\%2oand\%20a\%2o Framework\%2ofor\%2oOngoing\%2oWork\%20on\%2oAsset\%2oRecovery.pdf (22.02.2021).

5 See: Chapter V 'Asset recovery' of the UN Convention against Corruption, 2004 (UNCAC). R. Ivory indicates a possible broad and narrow understanding of "asset recovery" in the 
the Stolen Asset Recovery Initiative (StAR), being associated with the United Nations Office on Drugs and Crime (UNODC) and the World Bank, covers the issue of asset recovery more broadly (from collecting intelligence to management of assets) than the UN Convention against Corruption (UNCAC). ${ }^{6}$

However, the EU's asset recovery policy is fragmented rather than comprehensive, as it treats the inextricably linked objectives of a criminal trial in a disjointed manner. This is reflected by attempting to solve complex problems only during the individual sections, which results in excessive barriers to cross-border cooperation in criminal matters. An example where the objective of gathering evidence meets the objective of securing assets for future confiscation is the cross-border search for information on liquid financial assets held in the accounts of a bank or other financial institution. The same objects can be treated as evidence or recoverable assets, and their role can dynamically change during criminal proceedings.

The EU's policy should begin to take due account of the fact, so far overlooked, that the request in a European Investigation Order (an EIO) to undertake investigative measures aimed at identifying financial assets on an account in a bank or non-banking institution serves not only evidentiary purposes in a criminal case, but also, and in most cases probably primarily, serves to secure (freeze or seize) liquid assets for future confiscation. Although the EIO process was originally created for the purpose of cooperation in the gathering and preservation of evidence, the current state of cross-border cooperation in criminal matters shows that it would be desirable to develop it towards a more multi-faceted application, more suited to the complex purposes of criminal proceedings. ${ }^{7}$

context of the UNCAC, first "purposive" and second "procedural", see: R. Ivory, Corruption, Asset Recovery, and the Protection of Property in Public International Law. The Human Rights of Bad Guys (Cambridge: Cambridge University Press, 2014) p. 22-28. See also: D. Ziouvas, 'International Asset Recovery and the United Nations Convention Against Corruption', in C. King, C. Walker, J. Gurulé, eds., The Palgrave Handbook of Criminal and Terrorism Financing Law, Vol. 1 (Cham: Palgrave Macmillan, 2018) pp. 593-594.

6 https://star.worldbank.org/focus-area/asset-recovery-process (22.02.2021). See also: T. S. Greenberg, L. M. Samuel, W. Grant, L. Gray, Stolen Asset Recovery. A Good Practices for NonConviction Based Asset Forfeiture (Washington D.C: the World Bank, 2009) pp. 9-10.

7 On the original purpose of an EIO, see: S. Ruggeri, 'Introduction to the Proposal of a European Investigation Order: Due Process Concerns and Open Issues', in S Ruggeri, ed., Transnational Evidence and Multicultural Inquiries in Europe. Developments in EU Legislation and New Challenges for Human Rights-Oriented Criminal Investigations in Cross-border Cases (Cham, Heidelberg, New York, Dordrecht, London: Springer, 2014) pp. 3-24; R. Voynova, 'Modern Instruments for Evidence - Gathering in Criminal Matters Across EU', International Conference Knowledge - Based Organization, Vol. XxIv, No. 2 (2018) 250-252; C. Heard, D. 
If we investigate the process of cross-border financial asset recovery following the scenario envisaged by EU standards, at the stage between identifying assets and freezing them, we encounter a major gap in securing the continuity of the entire process, which may thwart the efforts of the judicial authority seeking, and the judicial authority finding, these liquid assets through cross-border cooperation. The key to successful asset recovery is the continuity of this whole process, which, unfortunately, is interrupted at the point between the identification of financial assets and their regular freezing or seizure. The current EU legal framework thus creates an excessively high risk of identified assets being concealed, thereby preventing their subsequent confiscation.

This article focuses on identifying shortcomings in the EU's policy and legal framework, relating to the early stage of the financial asset recovery process that could jeopardise the goals of the entire asset recovery process. To verify whether the problems initially identified through the policy and normative analysis were in any way reflected in the practice of cross-border asset recovery, documents such as reports, conclusions and best practices, issued by the European Union Agency for Criminal Justice Cooperation (Eurojust) and the European Judicial Network (EJN) were also analysed.

The article presents the thesis that the purpose of gathering evidence cannot be fully separated from the purpose of asset recovery. The consequence of adopting such an assumption should be an evolution of the EU's policy away from dealing with these issues separately, towards linking them where necessary to ensure effective asset recovery. As a solution to the problems identified, the article proposes involving the EIO mechanism for asset recovery purposes. The proposed changes to the EU legal framework should allow for a smooth transition from the cross-border asset identification phase to the asset freeze phase and thus close the time gap at their interface that risks the concealing of assets from confiscation. The proposed development of the application of an EIO in cross-border cooperation in criminal matters is in line with the EU's policy of combating serious crime, an indispensable element of which are mechanisms preventing the use of assets related to crime. ${ }^{8}$

Manseli, "The European Investigation Order: Changing the Face of Evidence Gathering in EU Cross-Border Cases', New Journal of European Criminal Law, Vol. 2, Issue 4 (2011) 353-367; R. Belfiore, 'The European Investigation Order in Criminal Matters: Developments in Evidencegathering across the EU', European Criminal Law Review, Vol. 5, Issue 3 (2015) 312-324. See also: Judgment of the Court (First Chamber) in Case C-324/17, Ivan Gavanozov, 24 October 2019, ECLI:EU:C:2019:892, Opinion of Advocate General Yves Bot delivered on 11 April 2019, Case C-324/17, Criminal proceedings against Ivan Gavanozov, ECLI:EU:C:2019:312.

8 Compare: L. Paoli, C. Fijnaut, 'Organised Crime and Its Control Policies', European Journal of Crime, Criminal Law and Criminal Justice, Vol. 14, Issue 3 (2006) 314; F.G. Inchausti, 'Mutual 
The issues of the deficiencies in the EIO mechanism will be developed in the following manner. First, the assumptions accompanying the planning of the EIO mechanism disregarding the convergence of the objectives of the criminal process will be presented (Section 2). Then, the possibilities of using the EIO mechanism to identify financial assets in bank and other financial accounts will be discussed, as well as the problem of the lack of special provisional measures intended to secure these assets (Section 3 ). In order to show the difficulties in the initial phase of the asset recovery process caused by the need to use two different mechanisms for cross-border cooperation, an example of a fictitious scenario for this phase will be presented (Section 4). The shortcomings of the EIO mechanism identified in the practice of Eurojust and the EJN will then be discussed (Section 5). Afterwards, the proposals for solutions to the identified problems will be presented (Section 6). Considerations will end with the conclusions presented in the last part of the article (Section 7 ).

\section{Limiting a European Investigation Order to Asset Identification}

In the literature, there have been criticisms of the legislative process preceding the adoption of Directive 2014/41/EU of the European Parliament and of the Council of 3 April 2014 regarding the European Investigation Order in criminal matters ${ }^{9}$ (hereinafter Directive 2014/41/EU or the EIO directive)..$^{10}$ However, a certain amount of criticism can still be added around the legislative path of the EIO directive. When designing this mechanism of cross-border cooperation in criminal matters, sight was lost of the various functionally related objectives of the criminal trial. Instead, the issue of gathering evidence was separated out, in a manner inconsistent with the needs of criminal proceedings. ${ }^{11}$ Possible wider usage of the EIO mechanism was not discussed at all at the time of its planning, therefore an incorrect assumption was made as to

Recognition and Transnational Confiscation Orders', in S. Ruggeri, ed., Transnational Inquiries and the Protection of Fundamental Rights in Criminal Proceedings (Berlin, Heidelberg: Springer 2013) p. 254; K. Ligeti, V. Franssen, 'Current Challenges in Economic and Financial Criminal Law in Europe and the US', in K. Ligeti, V. Franssen, eds., Challenges in the Field of Economic and Financial Crime in Europe and the US (Oxford: Hart Publishing 2017) pp. 10-15.

9 OJ L 130, 1.5.2014, p. 1.

$10 \quad$ For example: B. Schünemann, The European Investigation Order: A Rush into the Wrong Direction, in S. Ruggeri, ed., Transnational Evidence..., op. cit., pp. 29-35.

11 Compare: Commission of the European Communities, Green Paper on obtaining evidence in criminal matters from one Member State to another and securing its admissibility, 624 final, Brussels, 11.11.2009; Initiative of the Kingdom of Belgium, the Republic of Bulgaria, 
the scope of its use. Nevertheless, specific investigative measures for obtaining information on financial assets were incorporated into the EIO mechanism, which meant that, despite erroneous legislative assumptions, this cross-border cooperation instrument de facto went beyond the purposes of gathering evidence. From this perspective, it was justified to change the nomenclature of the new cooperation mechanism to "European Investigation Order". Council Framework Decision 2008/978/JHA of 18 December 2008 on the European evidence warrant for the purpose of obtaining objects, documents and data for use in proceedings in criminal matters, regulating the previous mechanism, used the term "European Evidence Warrant". ${ }^{2}$ However, as it then turned out, the mixed purpose of such special investigative measures has created some difficulties for practical cooperation in cross-border asset recovery.

The Tampere Conclusions seem to treat the issues of gathering evidence and securing assets as closely-related investigative actions, stating that: "The principle of mutual recognition should also apply to pre-trial orders, in particular to those which would enable competent authorities quickly to secure evidence and to seize assets which are easily movable; evidence lawfully gathered by one Member State's authorities should be admissible before the courts of other Member States, taking into account the standards that apply there" (point 36 ). ${ }^{13}$ Moreover, the "Programme of measures to implement the principle of mutual recognition of decisions in criminal matters" 14 determines the purpose of obtaining evidence in the context of the enforcement of pre-trial orders as follows: "To ensure that evidence is admissible, to prevent its disappearance and to facilitate the enforcement of search and seizure orders, so that evidence can be quickly secured in a criminal case (point 36 of the conclusions of the Tampere European Council)". ${ }^{15}$ Nevertheless, the "Green Paper on obtaining evidence in criminal matters from one Member State to another and

the Republic of Estonia, the Kingdom of Spain, the Republic of Austria, the Republic of Slovenia and the Kingdom of Sweden for a Directive of the European Parliament and of the Council of ... regarding the European Investigation Order in criminal matters, 2010/C 165/02, oJ C 165, 4.6.2010, p. 22.

12 OJ L 350, 30.12.2008, p. 72. Compare: A. IJzerman, 'From the CATs Portfolio: The European Evidence Warrant', in J.A.E. Vervaele, ed., European Evidence Warrant. Transnational Judicial Inquiries in the EU (Antwerpen, Oxford: Intersentia, 2005) pp. $5^{-16 .}$

13 European Council, Presidency Conclusions, Tampere, 15-16.10.1999.

14 Programme of measures to implement the principle of mutual recognition of decisions in criminal matters, OJ C 12, 15.1.2001, p. 10.

15 Ibidem, Section 2.1.1. Additionally, the Programme indicated that "Article 26 of the European Convention on the Transfer of Proceedings in Criminal Matters of 15 May 1972 and Article 8 of the Rome Convention of 6 November 1990 on the Transfer of Proceedings in Criminal Matters should be borne in mind." 
securing its admissibility" treats the issues of collecting evidence and securing property separately, although it refers both to the Tampere Conclusions and the previously mentioned Programme. ${ }^{16}$

The difference between the identification of assets and the imposition of a provisional measure on them, resulting in a temporary restriction on their disposal, is that the latter action involves an element of coercion by interference with the right to property (in terms of the free disposal of property). However, the asset recovery process involves both the former and the latter investigative activities. The subject literature indicates that cross-border confiscation involves at least three procedural steps: an investigation involving the identification and location of property in a country other than the one in which the investigation was initiated, securing the property after it is located, and the confiscation act itself. ${ }^{17}$

In the "Green Paper on criminal-law protection of the financial interests of the Community and the establishment of a European Prosecutor"18 the Commission presented a vision of the development of EU criminal policy towards extending the principle of mutual recognition to the investigative measures implemented in preliminary proceedings by the European Public Prosecutor, including intrusive measures, i.a. seizures and freezing of assets. ${ }^{19}$ A distinction was made regarding investigative measures with an element of coercion "subject to review by the courts: subpoenas, house searches, seizures, freezing of assets, interception of communications, covert investigations, controlled or supervised deliveries, etc."20 Relating the above distinction of

16 Commission of the European Communities, Green Paper on obtaining evidence in criminal matters from one Member State to another and securing its admissibility, Brussels, 11.11.2009, Сом(2009) 624 final. See: Section 2.

17 F.G. Inchausti, 'Mutual Recognition..., op. cit., p. 254.

18 Brussels, 11.12.2001, СОМ (2001) 715 final.

19 See: B. Hecker, 'Mutual Recognition and Transfer of Evidence. The European Evidence Warrant', in S. Ruggeri, ed. Transnational Inquiries..., op. cit., p. 273. See also the critical comments on 'Green Paper on criminal-law protection of the financial interests of the Community and the establishment of a European Prosecutor': C. Fijnaut, M. Groenhuijsen, 'A European Public Prosecutor Service: Comments on the Green Paper', in H.J. Albrecht, A. Klip, Crime, Criminal Law and Criminal Justice in Europe. A Collection in Honour of Prof. em. dr. dr. h.c. Cyrille Fïnaut, (Leiden: Brill 2013) pp. 550-551.

20 Commission of the European Communities, Green Paper on criminal-law protection of the financial interests of the Community and the establishment of a European Prosecutor, Brussels, 11.12.2001, СОМ (2001) 715 final. On the types of investigative measures identified in this Green Paper, see: K. Ligeti, 'The European Public Prosecutor's Office: Which Model?', in A. Klip, ed., Substantive Criminal Law of the European Union (Antwerpen: Maklu 2011) pp. $57-58$. 
investigative measures to the issues discussed in this article, provisional measures temporarily restricting the disposal of financial assets would be classified as measures with an element of coercion, but applied or approved by national judicial authorities.

\section{Identifying Financial Assets using a European Investigation Order}

Directive 2014/41/EU provides for the possibility of obtaining information on bank and other financial accounts. With the use of an EIO, it is possible to make certain enquiries about financial assets of natural or legal persons subject to the criminal proceedings. Firstly, whether the entity holds or controls an account or accounts with a bank or other financial institution (including information on accounts for which the person subject to the criminal proceedings has powers of attorney). If such accounts are identified, all their details can be obtained, to the extent that the information is in the possession of a bank or non-bank financial institution (Article 26 of Directive $2014 / 41 / E U)$. Secondly, an EIO gives the opportunity to obtain information on financial operations carried out on specific accounts during a defined period including the details of any sending or recipient account, to the extent that the information is in the possession of the bank or non-bank financial institution (Article 27 of Directive 2014/41/EU). However, regarding obtaining any information from a non-banking financial institution, there are additional grounds for non-execution of an EIO, if the execution of the investigative measure would not be authorised in a similar domestic case (Article 26 (6) and 27 (5) of Directive 2014/41/EU). Finally, it is possible to monitor activity (banking or other financial operations) on one or more specified accounts in real time (Article 28 of Directive 2014/41/EU). Similarly to the previous situation, there is an additional ground for refusing to execute such an investigative measure (requiring the gathering of evidence in real time, continuously and over a certain period of time) if its execution would not be authorised in a similar domestic case (Article 28 (1) in fine of Directive 2014/41/EU).

Although an EIO provides many possibilities for obtaining information on financial assets, its use is unfortunately limited to the identification of these assets. The question arises about what is missing in Directive 2014/41/EU to secure effective cross-border recovery of identified assets? Financial assets are characterised by high liquidity, and Directive 2014/41/EU lacks any provisional measures to prevent their disposal in order to avoid confiscation, prior to issuing and delivering a regular freezing order executed via a different mechanism 
of cross-border cooperation in criminal matters. While it provides for some provisional measures to preserve evidence, it does not provide for any measures to prevent the disposal of financial assets once they are identified. An EIO may be issued to take any measure with a view to provisionally preventing the destruction, transformation, removal, transfer or disposal of an item that may be used as evidence, but not to provisionally prevent transfer or disposal of financial assets that may be subject to future confiscation (Article 32 (1) of Directive 2014/41/EU). Therefore, other pathways for cross-border cooperation must be used to temporarily secure assets identified through an EIO.

In the context of this problem, the preamble to Directive 2014/41/EU emphasises the evidential purpose of the EIO mechanism and at the same time loses sight of the consequences of such a limitation. Recital 34 of the preamble highlights: "This Directive, by virtue of its scope, deals with provisional measures only with a view to gathering evidence. In this respect, it should be underlined that any item, including financial assets, may be subject to various provisional measures in the course of criminal proceedings, not only with a view to gathering evidence but also with a view to confiscation. The distinction between the two objectives of provisional measures is not always obvious and the objective of the provisional measure may change in the course of the proceedings. For this reason, it is crucial to maintain a smooth relationship between the various instruments applicable in this field. Furthermore, for the same reason, the assessment of whether the item is to be used as evidence and therefore be the object of an EIO should be left to the issuing authority".

The consequence of the necessity to change the cross-border procedure after asset identification and before securing them is a time gap in the asset recovery process. While this process should be a continuum of targeted actions, without adopting the correct point of view in this regard, EU instruments will not be able to ensure effective cross-border asset recovery.

\section{The Initial Stage of the Asset Recovery Process based on Two Different Mechanisms of Cross-Border Cooperation using the Example of a Fictitious Scenario}

The difficulties that may arise in the early stages of the asset recovery process can be illustrated by a simplified scenario of identifying assets under the EIO process and securing them for future confiscation under Regulation (EU) 2018/1805 of the European Parliament and of the Council of 14 November 2018 on the mutual recognition of freezing orders and confiscation orders 
(hereinafter Regulation 2018/1805). ${ }^{21}$ This Regulation replaced the provisions of Council Framework Decision 2003/577/J HA of 22 July 2003 on the execution in the European Union of orders freezing property or evidence ${ }^{22}$ (as regards the freezing of property between the Member States bound by this Regulation from 19 December 2020). ${ }^{23}$ This Regulation also replaced Council Framework Decision 2006/783/JHA of 6 October 2006 on the application of the principle of mutual recognition to confiscation orders ${ }^{24}$ (between the Member States bound by this Regulation from 19 December 2020). However, Denmark and Ireland do not participate in either Regulation 2018/1805 or Directive 2014/41/ $\mathrm{EU}$, therefore with regard to assets identified in their territories under the classical instruments of cooperation in criminal matters, Council Framework Decision 2003/577/JHA is still applicable to the cross-border execution of the freezing order. Furthermore, as regards the cross-border execution of confiscation orders, the above mentioned Decision 2006/783/JHA is still applicable in cooperation with Denmark and Ireland.

The possible difficulties in the initial stage of the asset recovery process result from the necessity to use two different EU instruments of cooperation in criminal matters to carry out activities essentially aimed at a single goal, which is to secure financial assets for future confiscation. The sequence of activities aimed at achieving this goal may follow the fictitious scenario below.

A prosecutor from Member State "A" (participating in Directive 2014/41/EU and Regulation 2018/1805) is looking for information about financial transactions being carried out on a specific bank account held by suspect " $\mathrm{X}$ " in a bank located in Member State "B" (participating in Directive 2014/41/EU and Regulation 2018/1805), including the details of any sending or receiving accounts. Additionally, the prosecutor is looking for information about the current balance of this account. According to the case file, this account was used by the suspect " $\mathrm{X}$ " to commit three frauds to the detriment of three different entities. The prosecutor has already received preliminary information about the suspect's bank account number in a specific bank in Member State "B" through the cooperation of National Asset Recovery Offices (AROs). ${ }^{25}$

\footnotetext{
21 OJ L 3O3, 28.11.2018, p. 1.

22 OJ L 196, 2.8.2003, p. 45.

23 See Article 39 of Regulation 2018/1805.

24 OJ L 328, 24.11.2006, p. 59.

25 On the EU legal framework for this cooperation, see: Council Decision 2007/845/JHA of 6 December 2007 concerning cooperation between Asset Recovery Offices of the Member States in the field of tracing and identification of proceeds from, or other property related to, crime, OJ L 332, 18.12.2007, p. 103; Council Framework Decision 2006/96o/J HA of 18 December 2006 on simplifying the exchange of information and intelligence between law
} 
However, the preparatory proceedings against suspect " $\mathrm{X}$ " are so advanced that there is a need to obtain information that may immediately constitute evidence, and not information of an operational nature that could eventually become evidence. ${ }^{26}$

On the one hand, the purpose of the prosecutor is to find additional evidence of these frauds and, on the other hand, to identify financial assets in order to secure them for future confiscation. The prosecutor operates under conditions of a certain urgency, the security of funds should take place before suspect "X" takes steps to conceal them to avoid future confiscation.

The evidentiary proceedings are pending. At the present stage of the criminal proceedings, the prosecutor has firmly established that the financial benefits obtained from the three frauds amounted to EUR 300,000, and the damage for each of these frauds amounted to EUR 50,000 for three different entities. In total, the prosecutor is seeking an amount of EUR 450,00O as security for future confiscation, including EUR 300,000 as security for future confiscation of the proceeds of crime and EUR 150,00o to secure confiscation for the purpose of restitution to the victims of the frauds. ${ }^{27}$

First, in order to obtain information on transactions on a specific bank account (held with a bank in Member State "B") in a given period of time and to obtain information on the current account balance, the prosecutor from Member State "A" issues an EIO (art. 27 (1) of Directive 2014/41/EU). Under the current legal framework for an EIO, the prosecutor should avoid disclosing in the EIO form that its purpose is not only to gather evidence but also to identify and secure financial assets for future confiscation, as he risks a refusal to execute such an EIO (on this topic, see Section 5 concerning problems with the execution of EIO s raised by Eurojust and the EJN). However, the tangled path leading to the recovery of EUR 450,000 in this fictitious case could be simplified if the legal framework of an EIO allowed the prosecutor to include the following conditional request in the EIO form: "request to carry out investigative measures in Member State "B" to obtain information on the history of transactions on a specific bank account during a specified period of time and to obtain information on the current balance of that bank account, and

enforcement authorities of the Member States of the European Union, oJ L 386, 29.12.2006, p. 89 (hereinafter Council Framework Decision 2006/96o/JHA).

26 See: limitations provided for in Article 1 of Council Framework Decision 2006/96o/JHA.

27 See: Article 8 (10) and Recital 29 of the preamble to Directive 2014/42/EU of the European Parliament and of the Council of 3 April 2014 on the freezing and confiscation of instrumentalities and proceeds of crime in the European Union, OJ L 127, 29.4.2014, p. 39; Articles 26 (2), 29, 30, 35 (2) (a), 38 (c) of Regulation 2018/1805 and Recitals 45, 46 and 48 of its preamble. 
if financial assets are identified in that account, the request to take the provisional measures to temporarily secure them up to an amount not exceeding EUR 450,000 for a period of up to 48 hours until the freezing order is issued and delivered."

The sequence of actions to identify financial assets through the EIO issued by the prosecutor under the current legal framework is as follows. A decision on the recognition or execution the EIO should be taken and the investigative measure should be carried out at the same time as in a similar domestic case in Member State "B". However as a rule, the deadline for execution of the EIO is 30 days after the receipt of the EIO by the competent executing authority (art. 12 (3), some modifications are provided for in art. 12 (5) of Directive 2014/41/EU). As regards provisional measures aimed at "securing evidence", the executing authority shall decide and communicate the decision on the provisional measure as soon as possible and, wherever practicable, within 24 hours of receipt of the EIO (art. $3^{2}$ (2) of Directive 2014/41/EU). The key problem is that Directive 2014/41/EU does not provide for similar provisional measures for "securing assets" for future confiscation, therefore the rule is the aforementioned maximum period of 30 days. Then, the executing authority shall carry out the investigative measure without delay, however, as a rule, within a maximum of go days following the taking of the decision on the recognition or execution the EIO (art. 12 (4), some modifications are provided for in Article 12 (6) of Directive 2014/41/EU). ${ }^{28}$

In this scenario, the prosecutor receives information from the authority executing the EIO that the current balance on the bank account being the subject of the inquiry is EUR 500,000, while the history of financial transactions from a given period indicates that the credits on the account totalled EUR 1,000,000.

The next sequence of actions takes place after the execution of the EIO. In order to secure the amount of EUR 450,00o for future confiscation, the prosecutor has to "switch" to a different path of cross-border cooperation in criminal matters. At this stage, the asset recovery process is interrupted. The follow-up action should be the issuance of a freezing or seizure order covering identified assets, to which Regulation 2018/1805 applies.

On the margins of considerations it should be noted that this terminological variation ("freeze" or "seize") can be confusing. ${ }^{29}$ Regulation 2018/1805,

28 The maximum period of 9o days applies, unless grounds for postponement under Article 15 of Directive 2014/41/EU exist or evidence mentioned in the investigative measure covered by the EIO is already in the possession of the executing State (Article 12 (4) of Directive 2014/41/EU).

29 See more about the concepts of freezing and seizing assets: J. Lelieur, 'Freezing and Confiscating Criminal Assets in the European Union', European Criminal Law Review, Vol. 5, Issue 3 (2015) 279-303. 
regarding the temporary securing of assets, only uses the term "freezing order", which covers both domestic freezing and/or seizure orders as known in different contexts in EU jurisdictions. The term "freeze" is commonly used regarding the securing of funds related to terrorism, but in the thematic field of recovery of assets, there may be nuances of meaning between the effects of a freeze or seizure in different national legal systems. ${ }^{30}$ The EU jurisdictions and international organisations use various terms for the temporary securing of assets linked with a crime, and this differentiation certainly influenced the nomenclature of EU law. An example of the use of different meanings of the terms "freezing" and "seizure" may be the Proceeds of Crime Act, 2002, hereinafter POCA. ${ }^{31}$ Another example is the understanding of these concepts at the FATF forum. ${ }^{32}$ In Regulation 2018/1805, the will of the EU legislator was to cover

$30 \quad$ See for example: Council Decision (CFSP) 2016/1693 of 20 September 2016 concerning restrictive measures against ISIL (Da'esh) and Al-Qaeda and persons, groups, undertakings and entities associated with them and repealing Common Position 2002/402/CFSP, OJ L 255, 21.9.2016, p. 25; Council Regulation (EC) No 881/2002 of 27 May 2002 imposing certain specific restrictive measures directed against certain persons and entities associated with Usama bin Laden, the Al-Qaida network and the Taliban, and repealing Council Regulation (EC) No 467/2001 prohibiting the export of certain goods and services to Afghanistan, strengthening the flight ban and extending the freeze of funds and other financial resources in respect of the Taliban of Afghanistan, OJ L 139, 29.05.2002, p. 9.

31 In the law applicable to England and Wales and Northern Ireland "a property freezing order" is an order that "specifies or describes the property to which it applies", and "subject to any exclusions (...) prohibits any person to whose property the order applies from in any way dealing with the property" (Section $245 \mathrm{~A}(2)$ of the POCA). The term "seizure" is used in POCA for "cash seizure" in the context of recovery of cash in summary proceedings (Section 294, applicable to U.K.), as well as in another context in sections: $41 \mathrm{~A},{ }_{47} \mathrm{C}$ (applicable to England and Wales), $35^{2}$ (applicable to England, Wales and Northern Ireland) of the POCA and in Part 2 or 3 of the Police and Criminal Evidence Act, 1984 (applicable to England and Wales).

32 The main difference between the terms "freeze" and "seize" is that the frozen property, equipment, instrumentalities, funds or other assets (depending on which FATF recommendation they refer to) remain the property of the natural or legal person(s) that held an interest in them at the time of the freezing "and may continue to be administered by third parties, or through other arrangements established by such person or entity prior to the initiation of an action under a freezing mechanism, or in accordance with other national provisions". Nevertheless, "as part of the implementation of a freeze, countries may decide to take control of the property, equipment, instrumentalities, or funds or other assets as a means to protect against flight". While a "seizure" is effected by "a mechanism that allows the competent authority or court to take control of specified property. The seized property remains the property of the natural or legal person(s) that holds an interest in the specified property at the time of the seizure, although the competent authority or court will often take over possession, administration or management of the seized property", FATF, International Standards on Combating Money Laundering and the Financing of Terrorism \& Proliferation. The FATF Recommendations, updated October 2020, pp. 124, 127, http://www.fatf-gafi.org/ media/fatf/documents/recommendations/pdfs/FATF\%2oRecommendations\%202012.pdf (26.02.2021). 
the widest opportunities of temporarily securing assets, taking into account terminological differences in this field. The term "freezing order" under this Regulation means "a decision issued or validated by an issuing authority in order to prevent the destruction, transformation, removal, transfer or disposal of property with a view to the confiscation thereof" (article 2 (1) of Regulation 2018/1805).

Returning to a critical point in the fictitious scenario of securing financial assets for future confiscation, the question is how to reduce the "lap time" occurring in the meantime (after the identification of financial assets with the use of the EIO and before their freezing on the basis of a regular procedural freezing order) and mitigate the risk of concealment of liquid financial assets identified as a result of the execution of the EIO. At this point of the asset recovery process, there is a need for urgent short-term provisional measures addressed to the assets which are missing in the current EU legal framework. The provisional measures were provided for in Article 32 of Directive 2014/41/ EU, but only to secure "an item that may be used as evidence".

In this fictitious scenario, the prosecutor uses the option of securing the financial assets identified with the EIO under the urgent procedure provided for in Article 9 (5) of Regulation 2018/1805. In the freezing certificate the prosecutor indicates that immediate freezing is necessary since there are legitimate grounds to believe that the property in question will imminently be removed or destroyed. Then the executing authority shall decide on the recognition of the freezing order no later than 48 hours after it has been received by the executing authority. Additionally, no later than 48 hours after such a decision has been taken, the executing authority shall take the concrete measures necessary to execute the order.

However, this urgent procedure follows a time gap that exists after the identification of the financial assets under the EIO and the effective transmission of this information to the EIO issuing authority, and prior to the issuance of a classic procedural freezing order and its effective transfer for cross-border execution under Article 9 (5) of Regulation 2018/1805.

\section{Shortcomings of European Investigation Orders identified in the} Practice of Eurojust and the European Judicial Network

The problem of the intersection of the objectives of securing evidence and securing assets for future confiscation was reflected in the practices of Eurojust and the EJN regarding EIOs. Difficulties in this context are reflected in the 
findings of the 2020 Eurojust report addressing the practical issues of EIO ${ }^{33}$ Analysis of this report, including proposed solutions to the problematic situations it identified, leads to the conclusion that it is impossible to find perfect solutions when dealing with an imperfect legal framework. The proposed solutions are instead an attempt to reduce obstacles in cross-border cooperation in criminal matters that cannot be completely eliminated without changes in EU law.

First of all, the 2020 Eurojust report talks about the "uncertainty" experienced by the cooperating authorities as to the right course of action when an object is needed for evidentiary purposes, and also has to be frozen for subsequent confiscation, or when the purpose of securing an object changes dynamically within a proceeding. ${ }^{34}$ Eurojust has previously noted cases in which the authorities executing the EIO questioned the official purpose of its issuance on the grounds that it was in fact issued for subsequent confiscation, and finally refused to execute such an EIO until they received a freezing certificate. ${ }^{35} \mathrm{An}$ example of Eurojust providing assistance was coordinating the expedited execution of a freezing order to ensure the continuity of the securing of the financial assets. Eurojust was asked to help with an urgent financial asset freeze, for which the bank applied a provisional measure on the amount alleged to be derived from criminal activity. Eurojust's help consisted of coordinating activities and providing additional information about the account owner, which made it possible to execute the EIO and the additional freezing order within the given time frame ( 2 days). ${ }^{36}$

This situation reflects the difficulty in smoothly transforming a bank's provisional measures on financial assets into a regular freeze on the basis of a procedural order. However, it should be remembered that as a minimum standard, the EU legal framework only provides for Member States to ensure that operations suspected of being related to money laundering or terrorist financing can be temporarily suspended by banks or other financial institutions. The obligation of the Member States to ensure that financial institutions take such provisional measures is provided for in the Fourth AML Directive (previously in

33 Eurojust, Report on Eurojust's casework in the field of the European Investigation Order, November 2020, (hereinafter the 2020 Eurojust report), https://www.eurojust.europa.eu/ sites/default/files/2O2O-11/2O2O-11_EIO-Casework-Report_CORR_pdf (25.02.2021).

34 Ibidem, p. 17.

35 Eurojust, Eurojust meeting on the European investigation order, The Hague, 19-2o September 2018, Outcome Report, December 2018, p. 5, https:/www.eurojust.europa.eu/sites/default/ files/Publications/Reports/2018-12_Outcome-Report_Eurojust-meeting-on-EIO-Sept2018_ EN.pdf (25.02.2020).

36 Eurojust, Report on Eurojust's casework..., op. cit., p. 12. 
the First and Third AmL Directives). ${ }^{37}$ According to Article $3^{2}$ (7) of the Fourth AML Directive, Member States shall ensure that a Financial Intelligence Unit (FIU) is empowered to take urgent action, directly or indirectly, where there is a suspicion that a transaction is related to money laundering or terrorist financing. This urgent provisional measure takes the form of suspension or withdrawal of consent to a transaction that is proceeding, in order to perform analysis, confirm the suspicion and disseminate the results of the analysis to the competent authorities. An FIU shall be empowered to take such action also at the request of an FIU from another Member State, for the periods and under the conditions specified in the national law. Moreover, the Fourth AML Directive in Article 35 requires Member States to ensure that obliged entities temporarily refrain from carrying out transactions which they know or suspect to be related to proceeds of criminal activity or to terrorist financing until they have completed the necessary actions related to the detection of such suspicious transactions. In order to meet these requirements, national legal systems have imposed various obligations on financial institutions ("obliged entities") to notify an FIU of suspicious transactions and to temporarily suspend the financial operation(s) on an account, a suspension that the FIU may extend the duration of. ${ }^{38}$

It is worth mentioning a similar obligation on the Member States to ensure the power of the national financial regulatory authority "to request the freezing and/or sequestration of assets" in the event of suspicion of market abuse (insider dealing or manipulation), resulted from Article 12 (2) (g) of the Market Abuse Directive (hereinafter the MAD). ${ }^{39}$ Currently, this power of the national financial regulatory authority is provided for in the Market Abuse Regulation

37 Fourth AML Directive: Directive (EU) 2015/849 of the European Parliament and of the Council of 20 May 2015 on the prevention of the use of the financial system for the purposes of money laundering or terrorist financing, amending Regulation (EU) No 648/2012 of the European Parliament and of the Council, and repealing Directive 2005/60/EC of the European Parliament and of the Council and Commission Directive 2006/70/EC, OJ L 141, 5.6.2015, p. 73. Similar obligation was provided for in Article 7 of the First AML Directive: Council Directive 91/308/E EC of 10 June 1991 on prevention of the use of the financial system for the purpose of money laundering, OJ L 166, 28.06.1991, p. 77 and in Article 24 of the Third AML Directive: Directive 2005/6o/EC of the European Parliament and of the Council of 26 October 2005 on the prevention of the use of the financial system for the purpose of money laundering and terrorist financing, OJ L 309, 25.11.2005, p. 15.

38 See more: A.H. Ochnio, Blokada rachunku i wstrzymanie transakcji jako środki przymusu w procesie karnym, [Blockade of account and suspension of transaction as coercive measures in criminal proceedings] (Warsaw: Wolters Kluwer, 2015) pp. 26-43.

39 Directive 2003/6/EC of the European Parliament and of the Council of 28 January 2003 on insider dealing and market manipulation (market abuse), O J L 96, 12.04.2003, p.16. 
(hereinafter the MAR).$^{40}$ The national financial regulatory authority shall have the power "to request the freezing or sequestration of assets, or both" (Article 23 (2) (i) of the MAR), without prejudice to the competences of the judicial authorities (Article 22 of the MAR). ${ }^{41}$

The minimum requirements of EU law regarding the application of urgent provisional measures to financial assets by the banks or other financial institutions are limited to money laundering and terrorist financing offences. ${ }^{42} \mathrm{In}$ cases where there is a suspicion of a link between the financial assets deposited in a given account and an offence other than the listed offences, national laws may not even provide for any possibility for banks or financial institutions to apply provisional measures, such as temporarily postponing the execution of a suspicious transaction, or temporarily blocking financial operations on a given account. This also applies to the categories of offences set out in Annex D to Directive 2014/41/EU. From this point of view, the EU legal framework does not ensure a smooth asset recovery process. It seems that the continuity of securing financial assets in this process could be improved in such a way that authorities (both issuing and executing an EIO) would have the opportunity to cooperate on their own without resorting to Eurojust's assistance when it is necessary to establish a provisional measure on financial assets. One possible way out of this problematic situation would be to supplement the EU legal framework for cross-border cooperation in criminal matters with the possibility of applying provisional measures closely related to those used in the AML/CFT mechanisms.

In addition, a number of other problems were observed in the practice of Eurojust in relation to the intersection of the objectives of securing objects for evidence and for future confiscation. Various solutions have been sought depending on the specific situation. If the object was needed for both purposes,

40 Regulation (EU) No 596/2014 of the European Parliament and of the Council of 16 April 2014 on market abuse (market abuse regulation) and repealing Directive 2003/6/EC of the European Parliament and of the Council and Commission Directives 2003/124/EC, 2003/125/EC and 2004/72/EC, OJ L 173, 12.6.2014, p. 1.

41 See also: A. H. Ochnio, Blokada rachunku..., op. cit., pp. 44-47; K. Ligeti, V. Franssen, 'Current Challenges...', op. cit., pp. 10-15.

42 Nevertheless, there are some external possibilities available to use, for example the Society for Worldwide Interbank Financial Telecommunication (sWIFT) network, used by the financial institutions, i.a. for immediate notification of suspected fraudulent financial operations on an account. See: SWIFT, The transformation of the European payments landscape, October 2018, pp. 10, 12, 13, 18, https://www.swift.com/swift-resource/185056/download?language=en (1.03.2021). See also: W. Blair, R. Brent, 'The Future of the International Law of Tainted Money', in W. Blair, R. Brent, eds., Banks and Financial Crime. The International Law of Tainted Money (Oxford, New York: Oxford University Press, 2008) pp. 481-482. 
but the purpose of evidence gathering prevailed, the EIO was considered an appropriate instrument of cross-border cooperation. There were also scenarios where the issuing authorities decided to separate issues initially covered by the letter of request (as a result of discussions in which Eurojust participated). The objects needed for evidentiary purposes were covered by an EIO, and the objects to be frozen or seized were covered by a freezing order, which, of course, was executed through a different path of cross-border cooperation. In some cases, as a result of the involvement of Eurojust, the real purpose of the request for securing the objects was clarified and the EIO was replaced with a freezing order. In other cases, when information on banking operations was requested in combination with the freezing of the available funds, the EIO was supplemented with a freezing order. In such cases, where the cross-border execution of the freezing order was separated from the execution of the EIO, Eurojust's coordination was necessary to ensure the urgent execution of the former. Finally, to overcome the difficult overlap between the purpose of securing evidence and securing assets for future confiscation, the 2020 Eurojust report recommended to use Section D of the EIO form to signal that a freezing order would be issued in the future. It must be noted, however, that this practice as recommended by Eurojust is far from perfect, as Section D should refer to an earlier EIO, and was not originally intended to deal with a situation where the issuing authority first seeks to identify assets that can still be subsumed into the purpose of gathering evidence, but in fact they are sought in order to secure them (freeze or seize) for future confiscation. ${ }^{43}$ Resorting to reliance on section D of the EIO form shows that Directive 2014/41/EU has not been adapted to the needs of multifaceted cross-border cooperation in criminal matters. From the perspective of the problems revealed by Eurojust and the EJN in the practical application of EIOs, the aforementioned Section D contains a scope that is too narrow, but which, in the absence of better solutions, is extended in specific cases to meet the needs of securing assets previously identified and treated as evidence.

The problems with overlapping evidence gathering and asset preservation objectives are also reflected in the "Joint Note of Eurojust and the European

43 Mentioned methods of solving difficult cases in the application of EIos were described in the 2020 Eurojust report. See: Eurojust, Report on Eurojust's casework ..., op. cit., pp. 18-19. On a similar use of Section D of the EIo form, see also: Eurojust, European Judicial Network (EJN), Joint Note of Eurojust and the European Judicial Network on the practical application of the European Investigation Order, June 2019, p. 5, https://www.ejn-crimjust.europa.eu/ejn/ libshowdocument/EN/2131/EN (25.02.2021); Council of the European Union, EJN Conclusions 2018 on the European Investigation Order, no. 14755/18, pp. 2, 8, https://www.ejn-crimjust. europa.eu/ejn/libshowdocument/EN/3096/EN (25.02.2021). 
Judicial Network on the practical application of the European Investigation Order" $2019 .{ }^{44}$ It was considered that an EIO does not cover freezing property for the purpose of subsequent confiscation, therefore a freezing order must be issued for this purpose. Furthermore, freezing and confiscation of property for restitution to an injured party is outside the scope of an EIO, therefore Article 8 of the Convention of 29 May 2000 on Mutual Assistance in Criminal Matters between the Member States of the European Union remains applicable. ${ }^{45}$ Currently, freezing and confiscation orders aimed at compensation or restitution for victims are subject to Regulation 2018/1805 (between the Member States bound by this Regulation) ${ }^{46}$ The limitation of issuing an EIO only for evidence purposes was also previously confirmed in the EJN Conclusions 2018 on an EIO, which stated that: "There is a common view among the EJN Contact Points that the EIO should be used if the primary aim is evidence gathering". ${ }^{7}$

In the context of the identified barriers to using an EIO to secure assets for future confiscation, the question arises of how to rebuild the EIO mechanism at the level of EU law to align it with both the purpose of evidence gathering, and the asset recovery process in its early stages: from the initial phase of identifying assets to the interim period before they are secured by a regular freeze or seizure order. On the one hand, asset identification has a mixed purpose (the purposes of gathering evidence and securing assets intersect here), but on the other hand, their securing (freezing or seizure) can in no way be subsumed into the purpose of gathering evidence, as it is clear that this serves the purpose of implementing future confiscation. Issuing an EIO for the purpose of identifying financial assets as well as for the purpose of securing them may result in a refusal to execute it. Unfortunately, the EU legal framework does not serve to mitigate this state of affairs.

\section{6 \\ Looking for Solutions to the Problems at the Intersection of Securing Evidence and Securing Assets for Future Confiscation}

Given the complex structure of the asset recovery process, which cannot be completed without gathering evidence, it would be desirable to open up a broad discussion on the redevelopment of the EIO mechanism so that

\footnotetext{
44 Eurojust, European Judicial Network (EJN), Joint Note..., op. cit., pp. 3, 14.

45 Ibidem, p. 16.

46 See: Recitals 45, 46 and 48 of the preamble and Articles 26 (2), 29, 30, 35 (2) (a), 38 (c) of Regulation 2018/1805.

47 Council of the European Union, EJN Conclusions 2018 on the European..., op. cit., pp. 2, 3.
} 
it also serves, to the extent necessary, to protect the recovery of assets. The starting point for finding new solutions should be the preliminary assumption that after identifying the assets, "switching" to another mechanism of EU cross-border cooperation should not be required in order to temporarily secure them, with a consequent time gap, before reaching the next half-step of using an EIO to recover liquid assets. This could be achieved, for example, by opening the possibility for an authority issuing an EIO to require the executing authority to take provisional measures on available financial assets identified with a bank or other financial institution, which may be modelled on AML/CFT mechanisms (Article 32 (7) and Article 35 of the Fourth AML Directive). Such provisional measures could be applied only for a short period of time, for example up to 48 hours, during which a regular freezing or seizure order would be issued and delivered. From the point of view of a smoother process of asset recovery and minimising the risk of hiding assets from confiscation, only after this intermediate step should there be a "switch" to another mechanism for cross-border cooperation in criminal matters as set out in Regulation 2018/1805. To sum up, the provisional measures should also be designed in Directive 2014/41/EU to secure assets for subsequent confiscation and not only to secure evidence (Article 32 of Directive 2014/41/ EU). AML/CFT mechanisms developed to temporarily suspend financial operation(s) on a bank account or other financial institution and cooperation of FIUs experienced in cross-border securing of financial assets could be used when planning detailed minimum standards for such provisional measures in the EIO mechanism.

The existing EIO mechanism offers the following investigative steps: determining whether a given person or entity holds or controls a bank or other financial institution account, obtaining detailed information about the identified account, obtaining the history of account operations in a given period, monitoring of banking or other financial operations that are being carried out through one or more specified accounts.

The proposed EIO mechanism should offer a further investigative step by enabling the inclusion in the EIO form, along with the request to search for financial assets, of the request for their provisional securing in the event of their positive identification. If financial assets are identified in a bank or other financial account, the EIO mechanism should allow for their provisional preservation by the same executing authority up to a specified amount for up to 48 hours until a regular freezing order is issued and delivered to this authority. In other words, the authority issuing the EIO should have the right to apply to the authority executing the EIO for provisional measures addressed to financial assets not only to "items" that may be used as evidence (Article $3^{2}(1)$ of 
Directive 2014/41/EU). For example in the form of requesting a bank or financial institution to suspend financial operation(s) on an account up to a specified maximum amount (if necessary and proportionate for the purposes of a given criminal proceeding, and limited to the categories of offences listed in Annex D to Directive 2014/41/EU) for a period of up to 48 hours, in order to execute a future freezing or seizure order. In the proposed model, the freezing or seizure order should be issued and delivered by the authority issuing the EIO within 24 hours from the moment this authority is informed by the authority executing the EIO about the effective application of provisional measures. Notification of the authority issuing the EIO about the effective execution of the provisional measures implemented by the authority executing the EIO should take place within 24 hours from the moment the request to suspend financial operation(s) on an account was submitted to the bank or other financial institution. The assets would then be secured in a smooth manner by a regular procedural freeze or seizure order executed under the urgency procedure provided for in 9 (5) of Regulation 2018/1805.

The proposed solution should be one of the thematic streams of the broader public debate on possible future development of the EIO mechanism with all the actors of the process of cross-border asset recovery in the EU, including National Desks reporting problematic situations with the application of EIO s to Eurojust and the EJN. Taking into account the realities of the current level of cooperation in criminal matters in the EU, the cross-border asset recovery process cannot, for obvious reasons, have a completely linear course. However, this remark also applies to the asset recovery process running under national procedures without a cross-border element. Even supplementing the EIO legal framework with urgent provisional measures to secure identified financial assets will not guarantee full linearity for this process. Nevertheless, the available instruments for cooperation in criminal matters in the EU should develop towards improving the asset recovery process as much as possible. The EIO mechanism seems to have the greatest potential and flexibility for this. Furthermore, it can be envisaged that the possibility of using an EIO also for purposes other than asset recovery will be tested by the issuing authorities. Taking into account the potential for EIO s to extend their use for various purposes, the question arises whether the limits of their application outside the strictly criminal field have not been set out in Article 4 of Directive 2014/41/ EU too broadly. ${ }^{48}$ The application of an EIO in specific cases, or attempts for

48 On the possible wider scope of application of an Eıo, see also: S. Ruggeri, Audi Alteram Partem in Criminal Proceedings. Towards a Participatory Understanding of Criminal Justice in Europe and Latin America (Cham: Springer 2017) p. 449. 
its application going beyond the assumptions accompanying the creation of this instrument of cross-border cooperation in criminal matters, will guide the future development of this instrument, with limitations resulting, inter alia, from the protection of fundamental rights and the purpose of combating crime in procedures with a criminal connotation. However it is uncertain how strong this connotation will have to be in the future development of the EIO mechanism.

\section{$7 \quad$ Conclusions}

Investigative measures in criminal proceedings pursue complex objectives. An example of this complexity is the link between the objectives of evidence gathering and asset recovery. From this point of view, EU policy regarding the linkage of these only seemingly separate objectives requires a comprehensive review to increase its coherence. The change of perspective, noting the convergence of the goals of the criminal process, would also reveal the untapped potential of the EIO mechanism for the initial phase of the asset recovery process. This mechanism should be seen within EU policy, according to its nomenclature, as a "European Investigation Order" and not just a "European Evidence Warrant".

What seems to be an achievable step to improve the cross-border recovery of assets in the EU is revising the EIO mechanism by complementing it with provisional measures for initial preservation of financial assets, after their identification, and before issuing and delivering regular freezing or seizure orders executed under Regulation 2018/1805. The current EIO legal framework allows for provisional measures only to secure an "item" that may be used as evidence, and not to secure the "assets" for future confiscation (Article 32 (1) of Directive 2014/41/EU). When planning such provisional measures addressed at financial assets, the models of provisional measures to secure such assets in bank accounts or other financial institutions used in AML/CFT mechanisms could be used.

The realities of the cross-border asset recovery process do not allow for the optimistic assumption that the proposed revision of the EIO mechanism will ensure full linearity of this process, by mitigating all risks of concealing assets from future confiscation. However, it offers the possibility of "sealing" the asset recovery process where an increased risk of asset leakage has been identified. Using the potential of the EIO mechanism for the initial phase of the asset recovery process may simplify the tangled path of asset recovery. 
The proposed solution should be seen as a theoretical emphasis on thematic streams of the broader public debate between all actors involved in the asset recovery process in the EU, including National Desks reporting problematic situations in the application of EIO s to Eurojust and the EJN.

\section{Acknowledgements}

This article was written within a research project "Standards for the confiscation of the proceeds of crime set in European Union law and their impact on Polish, German, French and English criminal law", No. 2019/33/B/HS5/01617, founded by the National Science Centre, Poland. 